\title{
Multiculturalism: An antidote to racism or untouched inequalities? A comparative study of second-generation Jamaicans and second-generation Portuguese in Toronto
}

\author{
Esra Ari, PhD Candidate, University of Western Ontario
}

\begin{abstract}
This research examines the effects of "race" and "class" on the economic and social integration of second-generation Jamaicans $(n=23)$ and Portuguese $(n=20)$ in Canada. This qualitative study uses interview data to compare the role of multiculturalism in the integration of two second-generation immigrant groups. I find that the integration of these two groups differs based on their visible minority status and their social class. These results are important to develop policies for the integration of racialized native-born youth into a multiethnic society.
\end{abstract}

Keywords: second-generation immigrants, integration, multiculturalism, segmented assimilation

\section{Introduction}

One out of twenty people in Canada is foreign-born (Statistics Canada, 2015) and the number of children born to foreign-born immigrants in Canada -second-generation- is growing fast (Statistics Canada, 2015; Statistics Canada, no date-a). Second-generation is "constituted by immigrants' children who are born and raised in the receiving society or, in some definition, merely raised there" (Silberman, Alba, Fournier, 2007, p. 1). From 2006 to 2011, the second-generation grew from $15 \%$ to $17.4 \%$ of the total Canadian population (Statistics Canada, 2015). Furthermore, three out of ten among the second-generation belong to a visible minority group.

Canada has witnessed a drastic change in its ethnic composition since 1962. The Canadian government had to abandon its long-standing country-of-origin immigration selection system because European societies were no longer able to provide sufficient labour for the demands of Canadian labour market (Green and Green, 1999; Simmons, 2010). Canada, hence, started to recruit immigrant workers from diverse ethnocultural backgrounds. In Canadian immigration history, this was a clear shift towards non-European sources of immigrants to Canada (Reitz \& Banerjee, 2007, p.1).

With the significant increase in the number of immigrants of colour, the context of immigrant integration in Canada has changed. During the first half of the 20th century, the classic linear assimilation model was guiding immigrants' integration (Driedger,1996, p. 30- 31; Plaza, 2006, p. 211). Linear assimilation is the process whereby new immigrants are expected to blend into the larger national culture (Driedger, 1996, p. 27) and to turn into undistinguishable members of the receiving country (Allahar, 2010, p. 72). The increasing ethnic diversity of Canadian society made this challenging, and led to the rise of the official policy of multiculturalism in 1971 (Reitz and Banerjee, 2007, p. 35).

Multiculturalism, as an official policy, guarantees that all minorities and immigrants can keep their distinct culture in the process of integration into the host society and have equal access to economic, social, and political institutions (Fleras \& Eliott, 1996, p. 328). However, various research and my interviews reveal that holding a visible marker of being racially different has been an obstacle to the integration process of immigrants of colour even for Canadianborn youth (Abada \& Linn, 2011; Allahar, 2010; Ari, 2016; Aydemir, Chen \& Corak, 2006; Brown \& Parekh, 2010; Codjoe, 2001, 2006; Davis, 2012; Henry, 1994; James, 2010, 2011; Plaza, 2006)

The specific focus of this paper is to understand the effectiveness of Canada's official multiculturalism policy in 
integration into Canadian society for young second-generation immigrants of colour, Jamaicans, and young secondgeneration non-visible minority group, Portuguese, in Toronto. My interviews with these two groups highlight the explanatory power of 'segmented assimilation' theory in Canada (Ari, 2016). I find that the outcomes of the integration process for Portuguese and Jamaican youth differ based on whether their minority status is visible or not and their social class. Multicultural ideology, hence, works in diverse ways for young second-generation immigrants.

\section{Methodology}

This paper is based on forty-three interviews with second-generation Jamaicans $(\mathrm{N}=23)$ and second-generation Portuguese $(\mathrm{N}=20)$ in Toronto, which I conducted for my PhD dissertation. Each interview was an average of 90 minutes in length. Because of this paper's specific focus on youth, the data for this manuscript comes from thirtytwo interviews with second-generation Jamaican-Canadian and Portuguese-Canadian youth who are between the ages of 18 and 35. Seven of the interviewees were Jamaican men, twelve were Jamaican women, nine were Portuguese women, and four were Portuguese men. When transcribing the interviews, I identified major themes, and then used these themes for coding the interview data.

It was initially difficult to access to Jamaican and Portuguese communities due to being an outsider to these communities. However, after getting access, my positioning allowed me to develop a perspective on complex social issues, concepts, and the relationships between them. My own social positioning as a doctoral student and as a first-generation (foreign-born) immigrant to Canada informed my interactions with my participants. I shared my personal history including the country I came from, my ethnic minority status in Canada, and some opinions when asked, which built a stronger communication and rapport with my informants. Indeed, I was not simply an outsider as Dowling (2010, p. 36) tells us a researcher is never "simply either an insider or an outsider" since I had sometimes similar characteristics such as social class, age, and minority status with some of my participants. My outsider status, on the other hand, benefited my research because my informants made an extra effort to provide detailed explanations and examples to me.

In this research study, there was a smaller number of male participants relative to the number of women. However, my interviews with male participants were enough to determine the major differences in men's and women's experiences. The research was approved by the Western University Health Science Research Ethnics Board on February, 2015 until February 2016.

\section{Background}

Black Caribbean immigration to Canada has been a highly racialized process because of the immigration policy of Canada. This policy made a clear distinction between "preferred" and "non-preferred" immigrants which excluded immigrants outside of Europe. There was a specific interest in attracting only white immigrants from northern and western Europe and the United States (Hawkins 1991:26-27). The entry of blacks was actively discouraged specifically because they were perceived as mentally inferior and unable to govern themselves which originated in the history of slavery and colonization. (Satzewich, 1990; Calliste, 1993/1994; Jakubowski, 1999; Plaza, 2001). Still, black Caribbeans were sometimes allowed in because of the need for cheap labour in some industries such as steel plants and mines (Calliste, 1993/1994, p.131; Plaza, 2001, p.43). However, it was not until 1955 that a significant number of Jamaicans entered Canada. When British women withdrew from domestic work in drastic numbers, and traditional countries were not able to send immigrants to fill their places because of the economic boom after World War II, one hundred women were recruited from Caribbean countries under the West Indian Domestic Schema; seventy-five of them were Jamaicans (Hick \& Allahar, 2011, p. 28, Satzewich, 1990, p.337, Plaza, 2001, p. 51). These women had to have at least an eighth grade education, pass the medical examination, be single, and work as domestics for at least one year upon their arrival to Canada. Indeed, most of the applicants for domestic work were 
teachers, secretaries, clerks, and so on, but they used this scheme as a legitimate tool to get into Canada (Plaza, 2001, p. 51).

After the withdrawal of the racist immigration policy in 1962, and the adoption of the point system in 1967, immigration from the Caribbean increased drastically until 1985 (Plaza, 2001, pp.54-58). Jamaicans are the most populous group among the Caribbean groups in Canada. As of 2011, the number of people who claimed Jamaican nationality was 256,915 , which makes up $0.8 \%$ of the total Canadian population (Statistics Canada, no date-a), and a majority of Jamaican-Canadians live in Toronto (Statistics Canada, no date-c). The economic well-being of Jamaicans is more fragile compared to the national average. In 2011 , while the unemployment level was $11.4 \%$ for Jamaicans, the national average was 7.8\% (Statistics Canada, no date-a). Furthermore, poverty statistics are alarming for the Jamaican community with a rate of $20.1 \%$ compared to a Canadian average of $14.9 \%$ (Ornstein 2006 , Statistics Canada, no date-a).

On the other hand, Portuguese immigrants, coming from southern Europe, were positioned between preferred and non-preferred immigrants. Portuguese immigration officially started in 1953 when Canadian and Portuguese governments cooperated to bring in five hundred and fifty men to work in agriculture and manual jobs (Higgs, 1982, p. 7). Immigrants from Portugal at that time largely came from rural and poor areas, and did not have more than a primary school education, and hence they have been overrepresented in unskilled and manual employment such as construction, manufacturing, and low skilled service jobs (Higgs, 1982; Nunes, 1998). During the 1980s, Portuguese immigration peaked, and Portugal was the eleventh most important origin country sending immigrants to Canada (Simmons, 2010, p. 126). Although immigration from Portugal continued in the 1990s, the number of Portuguese immigrants went down significantly, and, in the 2000s, it was no longer a major source country for Canada (ibid). As of 2011 , there were 429,850 individuals who claimed Portuguese origin, which was $1.3 \%$ of the total Canadian population, and a significant number of them are in Toronto and Montreal (Nunes, 1998; Statistics Canada, no datea). The Portuguese in Canada, despite their low education level, have a lower rate of unemployment at $7.7 \%$ than the Canadian average of $7.8 \%$ (Statistics Canada, no date-a) and lower rates of poverty compared to the Canadian average (Ornstein, 2006a, 2006b; Statistics Canada, no date-a). However, Portuguese-Canadians today are still overrepresented in manual and unskilled jobs.

\section{Theory, Evidence, and Discussion}

My interviews with second-generation youth highlight the importance of segmented assimilation theory in the Canadian context (Ari, 2016). This theory was developed to understand the economic and social integration of racial or new second-generation -the children of racial minorities- in the United States (U.S.) (Gans, 1992; Portes \& Zhou, 1993; Zhou, 1997; Zhou \& Kim, 2006). Essentially it suggests divergent outcomes of the integration process for the second-generation because of the increasing ethnic/racial diversity of immigrant groups after 1960s and recent changes in the economy due to the move from industrial to post-industrial society (Portes \& Zhou, 1993, p. 82; Zhou, 1997, p. 884). This theory argues that visible minority second-generation cannot become indistinguishable from the host society like European-origin second-generation immigrants because of various kinds of racisms and changing economic conditions in receiving developed countries (Gans, 1992, p. 174). Some visible minority secondgenerations, particularly working-class blacks and Latinos, are blocked from assimilating and get trapped by poverty in a post-industrial economy and cannot achieve upward mobility like previous European-originated secondgeneration immigrants.

The segmented assimilation and blocked assimilation models are based on research in the U.S. context and it is unclear the extent to which these models apply in the Canadian context. Canada differs from the U.S. in many ways such as higher level of educational attainment of Canadian second-generation visible minority groups compared to non-visible minority groups (Boyd, 2002; Reitz and Banerjee, 2007; Statistics Canada, 2011a). Furthermore, the 
socio-historical differences between Canada and the U.S., including the history of race relations, slavery, civil war, and the number of blacks in the U.S. could make the use of this theory challenging in Canada (Boyd 2002).

However, there has been some body of work confirming the main argument of segmented assimilation theory in Canada (Abada \& Linn, 2011; Ari, 2016; Aydemir, Chen \& Corak, 2006; Brown \& Parekh, 2010; Codjoe, 2001, 2006; Davis, 2012; Henry, 1994; James, 2010, 2011; Plaza, 2006). For instance, Aydemir, Chen and Corak (2006) found blocked educational mobility for some visible minority groups, especially for sons of immigrants from the Caribbean, Central and South America (p. 13). Furthermore, the findings based on higher level of educational attainment which refuse the segmented assimilation model within Canada do not provide an explanation for discrimination in institutions such as schools and labour market and in everyday life. A detailed analysis reveals that higher educational attainment of some second-generation immigrants of colour does not mean that they are not prone to be used as cheap and flexible labour (Allahar, 2010). For instance, although the educational level of Jamaicans is higher than Portuguese, their employment income is lower than Portuguese (Statistics Canada, 2011b).

My interviews show that segmented assimilation model applies in Canada depending on visible minority status and social class. In the labour market, some of my Jamaican participants, even the ones employed in decent jobs complained about having white supervisors with lower education, and racist attitudes of clients such as not wanting to be served by blacks. Participants in this study who are in transition from school to work explained that sometimes they face difficulty in job searching because of their addresses, such as Jane and Finch area where high number of black Canadians live, on their resumes. Black youth, as my interviews indicate, are stereotyped as "lazy, not being smart enough, violent, gangsta, and loud" among their teachers and society at large. They are disproportionately assigned to special education classrooms (Brown \& Parekh, 2010, p. 42; James, 2011, p.467) and applied courses to pursue college education instead of university sometimes regardless of their will.

Sarah (pseudonym) tells her schooling experiences as:

It was my first time being exposed to those stereotypes... When you are in middle school you don't think that there may be an issue because of the color you are. Not just the people, even the education system itself. You walk in there and teachers already have that idea of oh my God a Jamaican.... you are almost expected to fail. It was almost like you know when it comes time for like scholarships and that sort of things you are overpassed or you are not smart enough for... while I was there, I was always expected that I would be delayed kid. I would be the one that didn't do well in math or sciences because oh no the Asians always have that... So it was always the thing of trying to keep up because they think you are less than what you really are (Ari, 2016).

Portuguese youth coming largely from working-class families, on the other hand, according to the literature (Anisef, Brown, Phythian, Sweet \& Walters, 2008; Brown 1999, 2006, 2010; Nunes, 2008, 2014; Ornstein 2000, 2006a, 2006b) and my interviews, have significant educational problems, especially male Portuguese, including high drop out rates, underachievement, overrepresentation in special education classes, lack of familial guidance and role models, parents' limited English to help with school work, and being labelled as "troublemakers" at school. For instance, Portuguese students had the highest dropout rates among all language groups with 43\% in 2006 in the TDSB (Brown, 2006, p.15). However, compared to Jamaican second-generation youth, they are strongly connected to Canada and are proud of being a Canadian. It can be expected that by future generations, descendants of Portuguese immigrants will be indistinguishable part of Canadian society because there is not a resistance towards Portuguese community by the 2000s. This is not to deny the structural problems Portuguese youth face mostly originating from their working-class background. However, they don't see discrimination as a major problem on the ground of their ethnic identities.

Tom (pseudonym), working in construction, 33 years old second-generation Portuguese, said:

I feel grateful of being a Canadian citizen. We live in the best country in the world. We have the rights we want. 
We have every opportunity to do what we want to do. Freedoms, health care, education. You can become what you want to do in this country. If you work really hard, you can get what you want (Ari, 2016)

Black youth are also exposed to racial profiling, and find their daily lives restricted. Jamaican youth are followed for the suspect of theft at stores or male second-generation Jamaicans are stopped by police on the street and asked information without any concrete ground, which renders their integration process different than non-visible European originated immigrants.

Mike (pseudonym), a university student, 25 years old, tells his experience with police as:

I feel like I am harassed by police officers only because of my skin colour... or where I do live as well. I live in Rexdale....so I feel like I am discriminated against because I am a black male even if I am not doing anything or not causing trouble. An example of that is me being pulled over for like why are you walking? ... being pulled over while riding my bike, police asking questions where you are going? Can I see ID? What did I do? Just walking on the street? Those are instances that are discriminating (Ari, 2016).

Second-generation Jamaican youth face unique integration challenges stemming from systemic and institutional racism. However, this does not mean that all second-generation blacks experience blocked assimilation. While my middle-class Jamaican participants are more integrated in Canadian institutions, have more interaction with the rest of the society, and are better equipped to struggle with racism, working class second-generation are more disenfranchised from their social and economic rights in Canada due to their social class.

\section{Conclusion: The Role of Multiculturalism in Integration}

Diverse integration experiences of second-generation youth have shaped their perception of multiculturalism. There are significant variances within and between groups in their experiences of integrating into Canada depending on social class and visible minority status.

The ideology of multiculturalism shapes the integration of second-generation Jamaicans and Portuguese in three main ways. First group, all Portuguese youth and one-third of Jamaican youth for this study see multiculturalism as an inclusive model which creates a safe space for diversity and an opportunity to be exposed to different experiences such as ethnic food and festivals. Second-generation Portuguese youth regardless of their social class, within the context of this study, are not likely to experience ethnic tensions. On the other hand, Jamaican youth consider multiculturalism as an effective tool for fighting racism. Nevertheless, in spite of their belief in multiculturalism, some working-class Portuguese see some various affirmative action policies as an unfair treatment towards whites including themselves such as affirmative action in the hiring process.

Second, another one-third of black youth think that multiculturalism might not work in an ideal way but it is a positive step to achieve better resource distribution and to struggle against discrimination in the areas of labour market and education, and in their everyday lives. Third, to the rest of Jamaican youth, multiculturalism works as a hegemonic device which leaves systemic and institutional inequalities intact and maintains social order in a country with diverse ethnic and racialized groups. They think their everyday lives are imbued with different levels of racism, and state by paying lip services to multiculturalism distracts Canadians from structural inequalities. They do not consider Canada as home although born and raised in Toronto.

One clear difference among these two groups deserves attention. Skin colour of second-generation Jamaicans has reduced their chances of integration. Outcomes of integration differ along the lines of "race" and ethnicity in Canada which holds multiculturalism as an official policy. Although some black youth try to integrate into Canadian society, they face resistance because of the stereotypes about black people and structural constraints. In spite of the 
guarantee of equality under Multiculturalism Act (1988), second-generation immigrants face systemic challenges. Findings indicate that these challenges cannot be overcome easily for future generation blacks although youth have some control over their lives. Policies should aim to change the receiving society and its institutions as well instead of developing policies solely focusing on immigrant population and their children to make Canada more welcoming to racialized youth.

\section{Acknowledgments}

This research was partially funded by Faculty of Social Science and the Department of Sociology at the Western University. I would like to acknowledge my PhD supervisor Dr. Anton L. Allahar and my PhD dissertation committee member Dr. Fernando Nunes for their advice.

\section{References}

Abada, T. \& Linn, S. (2011). The Educational Attainments and Labour Market Outcomes of the Children of Immigrants in Ontario. Toronto: Higher Education Quality Council of Ontario

Allahar, A. (2010). The political economy of 'race' and class in Canada's Caribbean diaspora. American Journal of Political Economy, (8)2, 54-86.

Anisef, P., Brown, R., Phythian, K., Sweet, R., \& Walters, D. (2008). Early school leaving among students in Toronto secondary schools. CERIS Working Paper Series, No. 67 (pp.1-27). Toronto: CERIS.

Ari, E. (2016). [Multicultural Ideology: Getting beyond false consciousness: A comparative study of secondgeneration Jamaicans and second-generation Portuguese in Toronto]. Unpublished raw data.

Aydemir, A., Chen, W., \& Corak M. (2006). Intergenerational Earnings and Mobility among the Children of Immigrants. Analytical Studies Branch Research Paper Series (No. 316). Ottawa: Statistics Canada.

Boyd, M. (2002). Educational Attainments of Immigrant Offspring: Success or Segmented Assimilation. International Migration Review, 36(4), 1037-1050.

Brown, R. (1999). A Study of the Grade 9 Cohort of 1993, 1993-1998: The Last Grade 9 Cohort of the Toronto Board of Education. Report No. 229. Toronto: Academic Accountability, Toronto District School Board.

(2006). The TDSB Grade 9 Cohort Study: A Five-Year Analysis, 2000-2005. (\#05/06-05) Toronto: Toronto District School Board, Research and Information Services.

(2010). The Grade 9 Cohort of Fall 2004. Report No. 09/10-15. Toronto: Organizational Development Department, Research and Information Services, Toronto District School Board.

Brown, R. \& Parekh, G. (2010). Special education: Structural overview and student demographics (Research Report). Toronto, Ontario, Canada: Research and Information Services, Toronto District School Board.

Codjoe, H. (2001). Fighting a 'Public Enemy' of Black Academic Achievement - the persistence of racism and the schooling experiences of Black students in Canada. Race, ethnicity and Education, 4(4), 343-375.

. (2006). The role of an affirmed black cultural identity and heritage in the academic achievement of African-Canadian students. Intercultural Education, 17(1), 33-54.

Citizenship and Immigration. (1988). Canadian Multiculturalism Act. Retrieved from http://lawslois.justice.gc.ca/PDF/C-18.7.pdf.

Citizenship and Immigration. (2013). Annual Report on the Operation of the Canadian Multiculturalism Act: 20112012. Retrieved from http://www.cic.gc.ca/english/pdf/pub/multi-report2012.pdf. 
Citizenship and Immigration. (2014). Annual Report on the Operation of the Canadian Multiculturalism Act: 20122013. Retrieved from http://www.cic.gc.ca/english/resources/publications/multi-report2013/index.asp.

Davis, A. (2012). Project Groundings: Canadian and Jamaican Youth [Re]Define Violence. In James, C.E \& Davis, A. (Eds.), Jamaica in the Canadian Experience: A multiculturalizing Presence (Pp. 329-342.), Halifax \& Winnipeg: Fernwood Publishing.

Dowling, R. (2010). Power, Subjectivity, and Ethics in Qualitative Research. In I. H. (Ed.) Qualitative Research Methods in Human Geography, 3rd ed., Pp. 26-39. Don Mills, Ont.: Oxford University Press.

Driedger, L. (1996). Multi-ethnic Canada: Identities and Inequalities. Toronto: Oxford University Press.

Fleras, A., \& Eliott, J. L. (1996) Unequal Relations: An Introduction to Race, Ethnic, and Aboriginal Dynamic in Canada. Toronto: Pearson Hall Canada.

Gans, H. J. 1992. Second-generation decline: Scenarious for the economic and ethnic future of the post-1965 American Immigrants. Ethnic and Racial Studies, 15(2), 173-192.

Green, A., \& Green, D. (1999). The Economic Goals of Canada's Immigration Policy. Canadian Public Policy, 25(4), 425-451.

Hawkins, Freda. 1991. Critical Years in Immigration: Canada and Australia Compared. Montreal [Que.]: McGillQueen's University Press.

Henry, F. (1994). The Caribbean Diaspora in Toronto: Learning to live with racism. Toronto: University of Toronto Press.

Higgs, D. (1982). The Portuguese in Canada (booklet n. 2). Ottawa, ON: Canadian Historical Association.

James, C. (2010). Schooling and the University Plans of Immigrant Black Students from an Urban Neighborhood. In H. R. M. (Ed.) Culture, Curriculum, and Identity in Education, Pp.117-139. New York: Palgrave Macmillan.

(2011). Students "at Risk". Stereotypes and the Schooling of Black Boys. Urban Education, 22, 1-31.

Nunes, F. (1998). Portuguese Canadians From Sea to Sea: A National Needs Assessment. Toronto: PortugueseCanadian National Congress.

(2008). Striking a Balance in Canada's Diversity Dialogue: The Case of Portuguese-Canadian Community. Canadian Diversity. 6(2), 121-125.

(2014). The Underachievement of Portuguese-Canadian Youth: An Ongoing Phenomenon. International Network on Youth Integration. 5(1), 3-9.

Ornstein, M. (2000). Ethno-Racial Inequality in the City of Toronto: An Analysis of the 1996 Census. Toronto: Access and Equity Unit, City of Toronto.

Ornstein, M. (2006a). Ethno-Racial Groups in Toronto, 1971-2001: A Demographic and Socio-Economic Profile. Toronto: Institute for Social Research, York University.

(2006b). Ethno-Racial Groups in Montréal and Vancouver, 1971-2001: A Demographic and Socio-

Economic Profile. Toronto: York University, Institute for Social Research.

Plaza, D. (2001). A Socio-Historic Examination of Caribbean Migration to Canada: Moving to the Beat of Changes in Immigration Policy. Wabaggi Journal of Diaspora Studies. 4(1), 39-80.

. (2006). The Construction of a Segmented Hybrid Identity among One and a Half and Second-generation Indo- and African- Caribbean Canadians. Identity: An International Journal of Theory and Research. 6(3), 207-230 
Portes, A., \& Zhou, M. (1993). The New Second-generation: Segmented Assimilation and Its Variants. Annals of the American Academy of Political and Social Science, 530, 74-96.

Reitz, J., \& Banerjee, R. (2007, January 11). Racial Inequality, Social Cohesion and Policy Issues in Canada. Retrieved from http://irpp.org/research-studies/reitz-banerjee-2007-01-11

Satzewich V. (1990). Rethinking Post-1945 Migration to Canada: Towards a Political Economy of labour Migration. International Migration. 28 (3), 327-46.

Silberman, R., Alba, R., \& Fournier, I. (2007). Segmented Assimilation in France? Discrimination in the Labour Market against the Second-generation. Ethnic and Racial Studies, 30(1), 1-27.

Simmons, A. B. (2010). Immigration and Canada: Global and Transnational Perspectives. Toronto: Canadian Scholars' Press.

Statistics Canada. (2011a). Preparing for Success in Canada and the United States: The Determinants of Educational Attainment among Children of Immigrants. Retrieved from

http://www.statcan.gc.ca/pub/11f0019m/2011332/part-partie1-eng.htm

Statistics Canada (2011b). National Household Survey 2011. Retrieved from https://www12.statcan.gc.ca/censusrecensement/2011/dp-pd/index-eng.cfm

Statistics Canada. (2015). Generation Status: Canadian born Children of Immigrants. Retrieved from https://www12.statcan.gc.ca/nhs-enm/2011/as-sa/99-010-x/99-010-x2011003_2-eng.cfm.

(no date-a). 2011 National Household Survey: Data tables: Ethnic Origin (101), Age Groups (10), Sex (3) and Selected Demographic, Cultural, Labour Force, Educational and Income Characteristics (327) for the Population in Private Households of Canada, Provinces, Territories, Census Metropolitan Areas and Census Agglomerations, 2011 National Household Survey (Catalogue \# 99-010-X2011036) Last updated 2016-01-07.

http://www12.statcan.gc.ca/nhs-enm/2011/dp-pd/dt-td/Rp-

eng.cfm? LANG=E\&APATH=3\&DETAIL=0\&DIM=0\&FL=A\&FREE=0\&GC=0\&GID=0\&GK=0\&GRP=1\&PID=107647\&PRID= $0 \& P T Y P E=105277 \& S=0 \& S H O W A L L=0 \& S U B=0 \& T e m p o r a l=2013 \& T H E M E=95 \& V I D=0 \& V N A M E E=\& V N A M E F$ (accessed July 22, 2016).

(no date-b). Highlight Tables: Ethnocultural Portrait of Canada - Ethnic origins, 2006 counts, for Canada, provinces and territories - 20\% sample data. Last updated 2010-10-06. http://www12.statcan.ca/censusrecensement/2006/dp-pd/hlt/97-

562/pages/page.cfm?Lang=E\&Geo=PR\&Code=01\&Data=Count\&Table=2\&StartRec=1\&Sort=3\&Display=All\&CSDFilt er=5000 (accessed July 12, 2016).

(no date-c). The Jamaican Community in Canada. Last updated 2007-08-28

http://www.statcan.gc.ca/pub/89-621-x/89-621-x2007012-eng.htm\#1(accessed July 13, 2016)

Zhou, M., 1997. Segmented Assimilation: Issues, Controversies and Recent Research on the New Secondgeneration. International Migration Review. 31(4). 975-1008.

\& Kim S. (2006). Community Forces, Social Capital and Educational Achievement: The Case of Supplementary Education in the Chinese and Korean Immigrant Communities. Harvard Educational Review, 76(1), $1-29$. 